\title{
Smallholder dairy cattle production in coastal Kenya: resource base assessment and constraint identification
}

\author{
W. Thorpe', F. Chabari', S. Maloo', R. Muinga'2, A. Mukhebi', G. Mullins', J. Mureithi', \\ E. Mussukuya ${ }^{1,3}$, R. Nyambaka', M. ole Maki ${ }^{4}$, L. Otieno ${ }^{2}$, B. Perry', E. Rugema ${ }^{1}$ and E. Wekesa ${ }^{2}$ \\ 'International Livestock Centre for Africa, PO Box 80147, Mombasa, Kenya \\ ${ }^{2}$ Kenya Agricultural Research Institute, Regional Research Centre, PO Box 16, Kikambala, Kenya \\ 3 International Laboratory for Research on Animal Diseases, PO Box 30709, Nairobi, Kenya \\ 'Ministry of Livestock Developinent, PO Box 90952, Mombasa, Kenya
}

\section{Introduction}

Peri-urban smallholder dairy production in coastal lowland east and southern Africa has the potential to reduce the large milk deficit, to increase and stabilize farm income, create employment and catalyse agricultural development. Sustainable dairy production will require technical innovations appropriate to smallholder resources matched by the development of input and marketing services. This paper summarizes studies in coastal Kenya which assessed the resource base of smallholder farming systems. The objective was to define research priorities and development strategies through the identification of the major technical, social and economic factors constraining smallholder dairy production.

\section{Material and methods}

The high rainfall agro-ecological zones of coastal lowland Kenya are the semi-humid coconut-cassava (CL3) and the transitional cashewnut-cassava zones (CL4). CL4 borders on the semi-arid livestock-millet zone (CL5). The bimodal rainfall is variable in quantity and seasonal distribution. Soils are sandy, free draining and of low fertility. The population is growing at some $3.5 \%$ per annum, due in part to immigration from the densely populated highland areas. In late 1988 to 1990 recall and cross-sectional surveys were carried out in Kaloleni Division, a densely populated area of smallholder agriculture with some dairy development. The studies began in CL3 and CL4 with a farming systems survey of some 1900 smallholder households. It was followed in CL3, CL4 and CL5 by a cross-sectional disease prevalence survey of some $\mathbf{7 4 0}$ dairy cattle and 220 local zebu cattle, a census of cattle herds, and a farm enterprise budget survey. The latter sampled 77 farms stratified by zone, absence or presence and type of cattle and grazing system.

\section{Results}

In the farming systems survey a large proportion of households, $35 \%$, had no livestock and less than $20 \%$ had any cattle. Households were large, mean 10.8 (s.d. 6.08), with 7.8 (s.d. 5.53) permanent and 3.0 (s.d. 3.65) temporary residents. Nearly half were children. The average household had 1.8 male and 2.2 female permanent and 1.1 male and 0.4 female temporary adult residents. Households without livestock were significantly smaller, 9.4 compared with $13 \cdot 2$, than those having both cattle and small ruminants. Cropping systems were based on cash tree crops, invariably coconut and cashewnut, with shifting cultivation of the staples, maize and cassava, with peas, beans and rice. Intercropping was the rule. Only a small proportion of farmers used manure or fertilizer and then mainly on subsistence crops. Labour demand for crops was particularly high in the late dry and long rainy seasons. Almost all households had secure tenure of their one or more plots. Household plots were small, mode 2 ha; $75 \%$ were 6 ha or less. Households without livestock had on average smaller plots. Close to two-thirds had one or more additional plots within walking distance. There was little soil conservation and equipment was generally limited to hand tools for cultivation. Piped water was available to $75 \%$ of households and access roads were generally good. Fewer than $1 \%$ of houses had both permanent walls and roof.

Households without livestock, had off-farm income, while households with cattle were twice as likely to receive a pension or to run a business. The vast majority of households, over $80 \%$, relied on household income to fund farm improvements. More households in CL4 and those with cattle had used credit, often to buy dairy cattle. About one-third of households, especially those without cattle, were seeking credit, generally in CL3 for farm improvement and in CL4 to buy dairy cattle. About 
$20 \%$ of farmers rated lack of finance and diseases and pests as critical constraints on agriculture. They were generally mentioned by two to three times more respondents than any other single critical problem. Lack of finance was relatively less important in households with cattle. The other problem mentioned by more than $10 \%$ of respondents was animal food shortage by households having cattle.

In the farm enterprise budget survey, household and farm sizes were consistent with those in the farming systems study. Total farm labour supply averaged 1179 man-days per annum with twice as much female as male labour. Mean capital investment, excluding land, was about US\$4250 (1US\$ = Ksh23), mean total annual farm income was US\$980 (s.d. 740), and total annual household income was US\$3260 (s.d. 2890). Livestock contributed 21 to $61 \%$ of farm investment, 15 to $65 \%$ of farm income and 9 to $26 \%$ of total household income. The average farm contributed $30 \%$ and off-income (employment + business) $70 \%$ of mean household income. Mean per capita income was US\$300 (s.d. 195) per annum. In dairy herds, milk contributed, on average, $72 \%$ and animal disposal $27 \%$ of output value, and in zebu herds $29 \%$ and $69 \%$ respectively. In general, cattle contributed more to investment and income in drier than in wetter areas, in zebu than in mixed or dairy farms, and in less rather than more intensive systems. However higher resource productivity (profit per unit of farm resource) was associated with higher rainfall zones and more intensive systems.

The cattle census showed that in all zones at least $94 \%$ of the population were local zebu, but that in CL4 $10 \%$ of herds and in CL3 $17 \%$ of herds had all or some dairy cattle, mainly crosses. Dairy herds were small, $90 \%$ had 10 or fewer cattle. Most practised some concentrate feeding and acaricide use. While the large zebu population grazed extensively, onethird of dairy herds, mainly in CL3 and CL4, zero or semi-zero grazed. Zebu and dairy herds had similar structures, but the latter had twice as many lactating compared with dry cows as the former. In the long rainy season zebu cows in extensively grazed CL3 herds produced, on average, about $1 \mathrm{~kg}$ saleable milk per day compared with $6 \mathrm{~kg}$ or more from dairy cows. Results from the disease prevalence survey indicated that Theileria paria, a tick-transmitted parasite causing East Coast Fever, was endemic in the area. Antibody prevalence was high in calves, $64 \%$, and increased with age, suggesting that exposure of young dairy calves results in high mortality leaving an adult population immune to the local T. paroa strains. Trypanosome antigenaemia prevalence was also high, about $30 \%$, but no other important diseases were detected.

\section{Discussion}

The major natural resource constraints were a general deficiency of soil nutrients and unreliable and erratic rainfall distribution, problems which are becoming increasingly critical with greater population pressure. Farming is based on labour intensive, low-input, risk aversion practices yielding low output, and a dependence on off-farm income and cash from tree crops. Crop-livestock interactions are not exploited. Crop intensification and its integration with livestock are limited primarily by lack of capital, then by labour, and, for adoption of dairy cattle production, by disease risk. Required are access to credit and the development of capital and labour efficient systems for increased productivity of crops and livestock. Improvements in soil fertility and disease control will be key technical elements for successful adoption of dairy production, especially for the poorest households, those without livestock. 